\title{
Readiness of Young Fishermen in Malaysia to Use Global Positioning System: A Preliminary Result
}

\author{
Mohd Nizam Osman ${ }^{1}$, Siti Zobidah Omar ${ }^{2}$, Jusang Bolong ${ }^{1}$, Jeffrey Lawrence D’Silva ${ }^{2} \&$ Hayrol Azril \\ Mohamed Shaffril ${ }^{2}$ \\ ${ }^{1}$ Faculty of Modern Language and Communication, Universiti Putra Malaysia, Malaysia \\ ${ }^{2}$ Institute for Social Science Studies, Universiti Putra Malaysia, Malaysia \\ Correspondence: Mohd Nizam Osman, Faculty of Modern Language and Communication, Universiti Putra \\ Malaysia, Malaysia. E-mail: majudesa.desa1@gmail.com
}

Received: October 16, 2013 Accepted: March 19, 2014 Online Published: May 30, 2014

doi:10.5539/ass.v10n11p104 URL: http://dx.doi.org/10.5539/ass.v10n11p104

\begin{abstract}
The main attempt of this study is to determine the level of readiness possessed by young fishermen to use the Global Positioning System (GPS), and the potential problems they might face in relation to using the technology. The results presented in this study were the findings of the pre-test process conducted among 30 young fishermen at Kuala Paka and Kuala Terengganu. Overall, four factors of readiness were studied, and the results show that the respondents were labelled as being ready to go ahead with using GPS in relation to the factor of readiness of the individual young fishermen and the factor of readiness of young fishermen. In addition to this, the respondents were labelled as being not ready to use GPS when it comes to the remaining two factors, namely readiness of infrastructure and readiness of agencies. The respondents agreed that the agencies were the main problem that was hindering their use of GPS. While the findings discussed were merely the preliminary findings, they are an early indicator of what the actual data might be.
\end{abstract}

Keywords: young fishermen, community development, technology usage, readiness

\section{Introduction}

Technology evolution has benefited various industries in Malaysia, one of those industries being the fishing industry. A number of technologies have been invented to further assist and develop the fishing industry. Fishery technologies such as sonar, echo sounder, radar and mobile phone have been proven to benefit those who rely on it. Another technology that has a significant impact on the fishing industry is GPS. When compared to the old methods of fishing, the impact of GPS on the way the fishermen conduct their fishing operations is outstanding. A study by Abu Hassan et al. (2011) has proven that GPS has positively impacted the socio-economic aspects of the fishermen. However, even though it has such an undeniably positive impact, not all the fishermen in Malaysia use it, due to a number of problems. In a local study done by Omar et al. (2012), only 29 per cent of their sample relies on GPS for their fishing operation. Such a small number raises a query - are fishermen in Malaysia ready to use such technology? The main objective of this study thus attempts to discover the readiness of young fishermen to use GPS within their fishing operations, while at the same time intends to discover problems that might obstruct them from using GPS.

\subsection{The Fishing Industry and Fishermen in Malaysia}

The fishing industry has been admitted as one of the tools for enhancing communities' socio-economic aspects. The fishing industry has continuously attracted community attention; in 2006, the number of registered fishermen was 97,947, and in 2011, the industry had recorded a significant increase to 134,110 registered fishermen (DOF, 2011). Such an increase reflects the industry's strength in providing job opportunities to the community, particularly the younger members and those who settle in rural areas. In Malaysia, fishermen are encouraged to register with the Department of Fisheries Malaysia (DOF), and being a registered fishermen will allow them to receive a monthly allowance worth RM200 (roughly equal to USD66.6) and a fuel subsidy enabling them to get fuel at a rate that is 65 cents per litre cheaper than the market price. To be a registered fisherman, an individual must spent at least 120 days a year conducting their fishing operations, and 60 per cent of their main income must come from those operations. 
Fishermen in Malaysia are grouped into four catchment areas. Zone A is for the fishermen who conduct their fishing operations within 0-5 miles nautical; Zone B is for the fishermen who conduct their fishing operations within 5.1 to 12.0 miles nautical; Zone $\mathrm{C} 2$ is for the fishermen who conduct their fishing operations within 12.1 to 30.0 miles nautical; and Zone $\mathrm{C} 0$ is for the fishermen who conduct their fishing operations more than 30.0 miles nautical. Currently, according to studies done by Omar et al. (2012) and Shaffril et al. (2013), the majority of registered fishermen in Malaysia conduct their fishing routines within Zone A and Zone B areas. The fishing industry in Malaysia is still ruled by the 'veteran' fishermen. Local studies conducted by Omar et al. (2012), Bolong et al. (2012) and Abu Samah et al. (2012) have demonstrated a consistent finding, whereby only 30 per cent of their samples were among young fishermen (Note 1).

The number of registered vessels in Malaysia was on a consistent increase between 2006 and 2011 (DOF, 2011). Currently, there are a total of 53,002 registered vessels in Malaysia, where the majority can be found at states such as Sabah, Sarawak and Perak (DOF, 2011). Most of the registered fishermen in Malaysia rely on drift nets, trawl nets and fish purse-seines to conduct their fishing. In terms of productivity, statistics by the DOF (2011) have confirmed that a consistent flow of marine hauls has been recorded by the local fishermen - and use of advanced fishing technologies like GPS might further contribute towards such productivity.

\subsection{Benefits of GPS Usage}

\subsubsection{Reducing the Duration of Fishing Operations}

The principal function of GPS is to earmark a fishing spot by recording the latitude and longitude of the location, allowing fishermen to guide their vessels exactly to the marked fishing spot. Traditional methods of locating a fishing spot involved fishermen referring either to the mountainous/hilly locations or floating pelampung, which tends to consume a lot of time. However, GPS enables them to reduce their fishing operation time by directing automatically them to the exact spot.

\subsubsection{Reducing Operation Cost and Energy}

As the duration of fishermen's fishing operations is reduced, it also cuts the expenses of several operational aspects. First, as GPS gears them exactly towards the marked spot, less fuel will be consumed for their vessels, as there is no need for extra searching effort. Second, reduced fishing operation also means lower costs for the crew members' salaries. Third, shorter fishing operations also means that fishermen consume less energy for their fishing operation.

\subsubsection{Increasing Income and Productivity}

The advantages of GPS also will help the fishermen double their fishing productivity. Compared to the old methods of searching for a fishing spot which are highly dependent on their indigenous knowledge, however, the GPS brings fishermen exactly to the spot where there is an abundance of fishes available. As productivity increases, it means more money for the fishermen.

\subsubsection{Tightening of Safety and Security Aspects}

GPS can tighten the safety and security aspects for fishermen in several ways. First, as the fishermen are vulnerable towards a number of risks during their fishing operation (e.g. big waves, heavy rain, strong winds), GPS can be used as a useful safety tool. During bad weather, for example, visibility might be lessened, and GPS can navigate the fishermen safely to the jetty (Omar et al. 2012). Second, GPS is seen as a useful safety tool for small vessels, as by setting the location of dangerous coral and high tides, any potential collisions that might wreck them can be avoided. Third, GPS functions as a measurement device for the speed and direction the boat should take in order to avoid high tides and winds. Fourth, for commercial vessels (operating in Zones C2 and $\mathrm{C} 0$ ), GPS makes them aware of international boundaries and helps them avoid any conflict.

\subsubsection{Enhancing Technology-Literacy Skills and Reducing Digital Gaps}

In a view by Abu Hassan et al. (2011), GPS is found to enhance communities' technology-literacy and skills because fishermen who are exposed frequently to GPS might have the opportunity to learn and use such technology, which then increases their understanding of and compatibility with how GPS works and can benefit them in their fishing operations. This will eventually lead to reduction in the digital gaps between those in rural and urban areas.

\section{Methodology}

This a quantitative study, and the data presented in this paper was generated from the pre-test results. To gain the data needed, a questionnaire was developed based on comprehensive reviews of literature and past studies. The original questionnaire consists of five main parts, however, for the purpose of this paper, only three parts are 
included, namely demographic, readiness to use GPS, and problems associated with GPS usage. The respondents were given an open-ended or closed-ended option of answers for the demographic part, while for readiness and problem part, the respondents were given a five Likert-like scale option that ranged from one (strongly disagree) to five (strongly agree). After the questionnaire was completed, the pre-test process was conducted, whereby a total of 30 registered young-fishermen at Kuala Paka and Kuala Terengganu were chosen as the respondents. The data collection process was based on a survey method and assisted by a total of five trained and experienced enumerators. To analyse the data, SPSS was utilized whereby analysis such as frequency, percentage, mean and standard deviation were performed. The readiness level was measured based on a study done by Sutrisno and Lee (2010), who originally measuring the readiness level of extension officers towards an ICT program (Figure 1). While the study conducted by them is different in its focus, the researchers have, however, modified the instrument developed by them to match the fishermen settings, and further modified it based on the database of several established online journals.

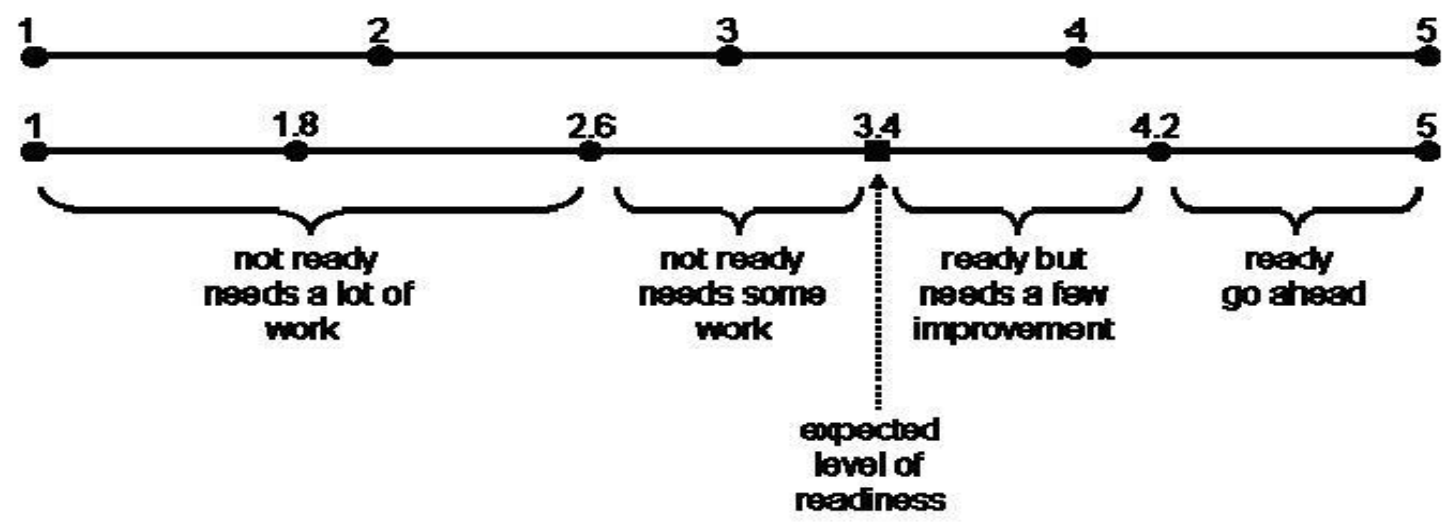

Figure 1. Level of readiness suggested by Sustrisno and Lee (2010)

\section{Results and Discussion}

\subsection{Demographic Data}

Table 1 demonstrates the demographic data of the respondents. There was an equal distribution of the respondents with regards to the group age, and the average mean score recorded was 31.1 years. In line with several local studies, the majority of the respondents were found to possess a low level of education. Man (2008) has explained this scenario by stating that educated youths are hesitant to join agriculture as they perceive it as their second choice of career. Average income per month recorded was RM816.7 (roughly equal to USD272.2) which exceeds the poverty level set by the Malaysian Economic Planning Unit (RM720 - roughly equal to USD240). The respondents can be considered to be experienced fisherman based on the mean score recorded for experience being 14.1 years, as well as that seven of them were identified as having been involved in the fishing industry for more than 21 years. The majority of the respondents were found to spend more than 16 days per month conducting their fishing operations - an important fact, given that registered fishermen are required to spend at least 120 days per year conducting their fishing operations. A total of 60.0 per cent of the respondents were crew members, while two thirds of them ( 66.7 per cent) were conducting their fishing operation within Zone A. 
Table 1. Demographic data

\begin{tabular}{|c|c|c|c|c|}
\hline Variables & Frequency & Percentage & Mean & S.D \\
\hline Age & & & 31.1 & 7.2 \\
\hline 30 years and below & 15 & 50.0 & & \\
\hline 30 years and above & 15 & 50.0 & & \\
\hline \multicolumn{5}{|l|}{ Level of education } \\
\hline Never been to school & 1 & 3.3 & & \\
\hline Primary school & 6 & 20.0 & & \\
\hline PMR/SRP/LCE & 8 & 26.7 & & \\
\hline SPM/MCE/SPMV & 15 & 50.0 & & \\
\hline Income per month & & & 816.7 & 489.0 \\
\hline$<$ RM500 & 9 & 30.0 & & \\
\hline RM501-RM1000 & 17 & 56.7 & & \\
\hline$>$ RM1001 & 4 & 13.3 & & \\
\hline Experience as a fisherman & & & 14.3 & 8.3 \\
\hline$<10$ years & 14 & 46.7 & & \\
\hline $11-20$ years & 9 & 30.0 & & \\
\hline$>21$ years & 7 & 23.3 & & \\
\hline Days per month spent at sea & & & 18.1 & 7.1 \\
\hline$<15$ days & 10 & 33.3 & & \\
\hline 16-20 days & 9 & 30.0 & & \\
\hline$>21$ days & 11 & 36.7 & & \\
\hline \multicolumn{5}{|l|}{ Fishermen category } \\
\hline Skipper & 11 & 36.7 & & \\
\hline Crew member & 18 & 60.0 & & \\
\hline Skipper and crew member & 1 & 3.3 & & \\
\hline \multicolumn{5}{|l|}{ Catching area } \\
\hline Zone A & 20 & 66.7 & & \\
\hline Zone B & 10 & 33.3 & & \\
\hline
\end{tabular}

\subsection{Readiness towards GPS Usage}

With regards to fishermen's readiness to use GPS, a total of four readiness factors were measured, and it can be seen that the factor of readiness of the individual young fishermen scored the highest mean score $(\mathrm{M}=4.43)$, while the factor of readiness of infrastructure recorded the lowest mean score $(M=3.18)$ (Table 2). Referring to the readiness level suggested by Sutrisno and Lee (2010), respondents were labelled as being ready to use GPS but in need of a few improvements (mean score between $3.40-4.20$ ) in the factor of readiness of young fishermen (refers to how the respondents perceived their fishermen colleagues readiness to use GPS), while the respondents were labelled as being those who are ready to use GPS for the factor of readiness of the individual young fishermen (refers to how the respondents perceived their readiness to use GPS). Furthermore, respondents were labelled as being those who are not ready to use GPS and need some work in the remaining two factors, namely readiness of infrastructure and readiness of agencies. From the data, it can be concluded that the fishermen themselves felt that they were ready to use GPS while at the same time felt that their colleagues needed some help to further encourage and motivate them to use the GPS within their respective fishing operations. 
Table 2. Overall mean score on readiness for GPS usage

\begin{tabular}{ll}
\hline Readiness & Mean \\
\hline Readiness of young fishermen & 3.95 \\
Readiness of the individual young fisherman & 4.43 \\
Readiness of infrastructure & 3.09 \\
Readiness of agencies & 3.18 \\
\hline
\end{tabular}

Referring to Table 3, the respondents perceived themselves and their colleagues as being ready to use GPS in their fishing operations. This result is not surprising, as it can be related to their age. Age has long been identified as main impingement factor for technology usage and acceptance. According to Shaffril et al. (2010) and Lee et al. (2005), young people are more likely to use technology than older people, and in line with the average age (31.1 years) of the respondents in the study, the readiness to use GPS of the young fishermen documented in this study is no surprise.

Support from the government, either in the form of social, economic or infrastructure, is crucial in encouraging the community to use the technology that is introduced to them (Malamud and Pop-eleches, 2010). Nonetheless, within the scope of this preliminary finding, it can be seen that the current available infrastructure and relevant agencies were seen as not being ready to support GPS usage among young fishermen, and that this, according to the respondents, occurs due to a lack of available funds. However, despite this low level of readiness, the respondents have expressed their satisfaction toward the GPS satellite signal. The main thing that should be highlighted here is with regards to the lack of technical support, GPS workshops and government plans to support the wider use of GPS. Analyses performed have also concluded that there is a lack of GPS courses, seminars and agency officers in place to support and encourage GPS usage among young fishermen. The availability of these - particularly the courses and seminars - is important to further motivate people to use technology (Shaffril et al., 2010; Carey et al., 2002). 
Table 3. Readiness among young fishermen to use GPS

\begin{tabular}{lc}
\hline Readiness of young fishermen & Mean \\
\hline Young fishermen know that GPS can be used in their fishing operation & 3.87 \\
Young fishermen know how to manage their time using GPS & 4.10 \\
Young fishermen do have adequate skills regarding GPS usage & 3.93 \\
Access to GPS is not a problem to young fishermen & 3.67 \\
I think that young fishermen are ready to use GPS & 4.17 \\
Readiness of individual young fisherman & Mean \\
I know that GPS can be used as a tool in my fishing operations & 4.53 \\
I am ready to use GPS as it is useful in learning and extension processes & 4.30 \\
I think now is the suitable time to promote GPS usage among young fishermen & 4.63 \\
I am ready to include GPS in my fishing operations & 4.50 \\
I have adequate ability to use GPS & 4.17 \\
Readiness of infrastructure & Mean \\
The available infrastructure in this area supports GPS usage among young fishermen & 2.80 \\
There is adequate technical support for use of GPS in this area & 2.77 \\
There are workshops to repair malfunctioning GPS units & 2.73 \\
The government has planned to upgrade the local ICT infrastructure & 2.77 \\
Satellite signal in this area is satisfactory & 4.37 \\
Readiness of agencies & Mean \\
The relevant agencies know how to use GPS & 3.47 \\
The relevant agencies encourage fishermen to use GPS & 3.60 \\
The relevant agencies have plans to enhance GPS usage among young fishermen in & 3.40 \\
the future & \\
The relevant agencies provide training and seminars with regard to GPS usage by & 2.60 \\
young fishermen & \\
The relevant agencies have an adequate number of officers available to assist young & 2.90 \\
The relevant agencies offer skilled officers who know how to use fishery technologies & \\
such as GPS & \\
\hline
\end{tabular}

\subsection{Problems to Use GPS}

A total of four problems that might obstruct the respondents from using GPS have been studied (Table 4). It is clear here that the respondents agreed that problems with regards to the agencies were the main influence, as this factor recorded the highest mean score. Furthermore, the problems related to the individual fishermen recorded the lowest mean score, which shows that this factor will obstruct them the least from using GPS.

Table 4. Overall mean score on problems of GPS usage

\begin{tabular}{ll}
\hline Problems & Mean \\
\hline Problems of agencies & 3.34 \\
Problems of individual & 1.91 \\
Problems of technology & 2.27 \\
Problems of policy & 2.81 \\
\hline
\end{tabular}


With regards to the obstacles the fishermen faced relating to individual problems, all of the items used recorded a low mean score $(M<2.33)$, except for the statement of 'Can't afford to have GPS', which recorded the mean score of 3.70. This mean score demonstrated that the current price of GPS is too expensive for the respondents. Within the local setting, the price of GPS, which ranges from RM800 to RM5000, and when compared to their average monthly income - RM816.70 - the current price of GPS is far too high for them. The premilinary findings are in line with the findings of Shaffril et al. (2010) who revealed that financial capacity is one of the impinging factors influencing technology usage, and conclude that those with adequate financial capacity will be exposed to technology usage to a greater degree, as they have the power to buy and use that technology - and, naturally, the oppostie is true of those who cannot afford to buy technology.

The respondents have raised their concerns with regards to the lack of support from the concerned parties to encourage and assist their use of GPS. The concerned parties, according to the respondents, have allocated a limited amount of funding to programs and training that would encourage GPS usage. Further action should be taken to overcome this problem, as consistent training and courses hold the key to the success of technology adoption among a community. According to Abu Hassan et al. (2009), consistent courses and seminars will help to continously educate and motivate the community into adopting technology.

Problems with regards to technology have demonstrated similar findings with individual problems, whereby the respondents have raised their concerns about the expensive price of GPS, and how it has obstructed them from buying and using such technology. Nonetheless, respondents were found to be aware of the the benefits GPS would have with regards to their fishing operations, as they expressed disagreement when asked to comment on the irrelevancy of GPS in their fishing routines. Furthermore, they were found to be ready to use GPS, as they have the skills and compatibility for using such technology in addition to the fact that the GPS signal in their area was deemed as being good and clear.

When it came to policy, the respondents expressed less concern about the existing laws with regards to technology usage. The problems with the current policy, according to the respondents, has much to do with a lack of funds to further encourage and promote the use of GPS. Furthermore, additional funding is needed to provide more GPS courses and seminars to young fishermen. 
Table 5. Problems faced by young fishermen with regards to using GPS

\begin{tabular}{|c|c|}
\hline Agencies & Mean \\
\hline The relevant agencies provide inadequate training with regard to GPS & 3.63 \\
\hline There are lacking of technical supports from the relevant agencies & 3.60 \\
\hline There is communication problem with the agency officers to share GPS information & 2.97 \\
\hline There is lacking of awareness on the GPS importance and benefits & 2.67 \\
\hline There is inadequate number of staff to educate fishermen to use GPS & 3.47 \\
\hline There is lacking of financial fund to organize program to encourage GPS usage & 3.70 \\
\hline Individual & Mean \\
\hline Have no confidence to use GPS & 1.67 \\
\hline Have no motivation to use GPS & 1.53 \\
\hline Language problem & 2.03 \\
\hline Have no interest in using GPS & 1.37 \\
\hline Have no skills in using GPS & 1.77 \\
\hline Have inadequate time to learn how to use GPS & 1.60 \\
\hline Cannot afford to own GPS & 3.43 \\
\hline Technology & Mean \\
\hline There is unsystematic development with regard to technology infrastructure within the fishing sector & 2.40 \\
\hline GPS cost is too expensive & 4.07 \\
\hline There is lack of GPS available in this area & 2.40 \\
\hline Cannot understand language in used in GPS & 2.10 \\
\hline GPS technology is irrelevant to fishing industry activities & 1.43 \\
\hline GPS technology is not user-friendly & 1.77 \\
\hline The available GPS satellite signal is weak & 1.70 \\
\hline Policy & Mean \\
\hline The existing government policy with regard to GPS usage among young fishermen is less effective & 2.27 \\
\hline The laws with regard to technology usage do not support GPS usage among young fishermen & 1.87 \\
\hline $\begin{array}{l}\text { There is limited financial funding provided by the relevant agencies to encourage GPS usage among } \\
\text { young fishermen }\end{array}$ & 3.23 \\
\hline Financial funding allocated for GPS courses/seminars/workshops is lacking & 3.33 \\
\hline There is a lack of funding to promote GPS usage by the relevant agencies & 3.33 \\
\hline
\end{tabular}

\section{Conclusion}

The main limitation of this study is that these are merely the preliminary findings, which involved a total of 30 young fishermen as the respondents, and that and the results might therefore be different if a bigger sample size were to be used. The number of respondents is far too small to claim universal validity, and not suitable to be considered as generally valid. However, even with this small number, this study can at least portay an early indication as to the level of of readiness of young fishermen to use advanced fishing technologies such as GPS within their fishing operations. To this end, the authors are currently conducting data collection for a bigger sample size (240 respondents) in four selected fishing districts, namely Mersing (in Johor), Pangkor Island (in Perak), Langkawi Island (in Kedah) and Kuala Besut (in Terengganu). The analysis that will be gained from the bigger sample size would be more representative and would portray a clearer picture as to the readiness of young fishermen to use GPS, as well as the problems they might face when it comes to using GPS. Furthermore, it is hoped that the findings from the bigger study will extend the available knowledge and understanding of young fishermen's readiness to use GPS, which is likely to spur new disciplines, cultures, and theoretical developments. 


\section{References}

Abu Hassan, M., Hassan, M. S., Shaffril, H. A. M., \& D’Silva, J. L. (2009). Problems and obstacles in using information and communication technology (ICT) among Malaysian agro-based entrepreneurs. European Journal of Scientific Research, 36(1), 93-101.

Abu Hassan, M., Shaffril, H. A. M., D’Silva, J. L., Omar, S. Z., \& Bolong, J. (2011). Fishermen and ICT: Towards creating knowledgeable fishermen in Malaysia. Australian Journal of Basic and Applied Science, 5(9), 457-469.

Bolong, J., Omar, S. Z., Shaffril, H. A. M., D’Silva, J. L., \& Abu Hassan, M. (2012). Communication technologies and fishermen: Lesson learned from Langkawi Island and Kuala Besut. Science Series Data Report, 4, 2-12.

Carey, J., Chisholm, I., \& Irwin, L. (2002). The impact of access on perception and attitudes towards computers: An international study. Educational Media International, 39(3\&4), 223-235. http://dx.doi.org/10.1080/09523980210166431

Department of Fisheries Malaysia (DOF). (2011). Number of fishermen working on licensed fishing vessels by fisheries districts. Retrieved November 17, 2013, from http://www.dof.gov.my/documents/10157/c935e111-a138-43e9-acfb-8d933f6d97fc

Lee, H., Lee, Y., \& Kwon, D. (2005). The intention to use computerized reservation systems: The moderating effects of organizational support and supplier incentive. Journal of Business Research, 58(11), 1552-1561. http://dx.doi.org/10.1016/j.jbusres.2004.07.008

Malamud, O., \& Pop-eleches, C. (2010). Home computer use and the development of human capital. The Quarterly Economics, 126(2), 987-1027. http://dx.doi.org/10.1093/qje/qjr008

Man, N. (2008). Youth perception and needs towards agriculture education. Journal of Youth Development, 1, 99-144.

Omar, S. Z., Shaffril, H. A. M., Bolong, J., D’Silva, J. L., \& Abu Hassan, M. (2012). Usage of offshore ICT among fishermen in Malaysia. Journal of Food, Agriculture and Environment, 10(3\&4), 1315-1319.

Shaffril, H. A. M., Abu Samah, A., D’Silva, J. L., \& Yassin, S. M. (2013). The process of social adaptation towards climate change among Malaysian fishermen. International Journal of Climate Change Strategies and Management, 5(1), 38-53. http://dx.doi.org/10.1108/17568691311299354

Shaffril, H. A. M., Abu Samah, B., Abu Hassan, M., \& D’Silva, J. L. (2010). Socio-economic factors that impinge computer usage in administration works among village leaders in Malaysia. Scientific Research and Essays, 5(23), 3623-3633.

Sustrisno, H. P., \& Lee, Y. (2010). An assessment of readiness and barriers towards ICT programme implementation: Perceptions of agricultural extension officers in Indonesia. International Journal of Education and Development using Information and Communication Technology, 6(3), 19-36.

\section{Note}

Note 1. According to the Ministry of Youth and Sport Malaysia, 'young' refers those whose age ranges between 15 and 40 years old.

\section{Copyrights}

Copyright for this article is retained by the author(s), with first publication rights granted to the journal.

This is an open-access article distributed under the terms and conditions of the Creative Commons Attribution license (http://creativecommons.org/licenses/by/3.0/). 